\title{
The rostral neurovascular system of Tyrannosaurus rex
}

\author{
Florian Bouabdellah, Emily Lessner, and Julien Benoit
}

\begin{abstract}
The study of the rostral neurovascular system using CT scanning has shed new light on phylogenetic and palaeobiological reconstructions of many extinct tetrapods. This research shows a detailed description of the rostral neurovascular canals of Tyrannosaurus rex including the nasal, maxillary (dorsal alveolar), and mandibular (ventral alveolar) canals. Extensive comparisons with published descriptions show that the pattern of these canals in Tyrannosaurus is not unusual for a non-avian theropod. As in the non-avian theropod Neovenator, the maxillary canal shows several anastomoses of its branches. Differences from the plesiomorphic sauropsid condition are concentrated within the canal for the maxillary neurovasculature, which is primitively horizontal, tubular, and connected to a single row of supralabial foramina, whereas in Tyrannosaurus the main trunk of the canal is oriented more obliquely and dorsally displaced to give room to the deep tooth alveolae. As a result, the lateral branches that provide innervation and blood supply to the skin are dorsoventrally elongated compared to non-theropod taxa, and multiple rows of supralabial foramina are present. An overview of the literature suggests that the evolution of the trigeminal canals among sauropsids only weakly supports previous hypotheses of crocodile-like facial sensitivity in non-avian theropods (except, maybe, in semiaquatic taxa). More systematic studies of the rostral neurovascular canals in non-avian theropods may help answer the question of whether lips were present or not.
\end{abstract}

Florian Bouabdellah. Universities of Poitiers, 15 Rue de l'Hôtel Dieu, TSA 71117, 86000 Poitiers, France. florian.bouabdellah@hotmail.com

Emily Lessner. University of Missouri School of Medicine, Columbia, MO, 65211, USA.

ejlessner@mail.missouri.edu

Julien Benoit. Evolutionary Studies Institute and School of Geosciences, University of the Witwatersrand, Johannesburg 2050, South Africa, julien.benoit@wits.ac.za

Keywords: Palaeoneurology; sense organs; CT scan; Tyrannosaurus; maxillary canal; lips; trigeminal nerve

Submission: 15 July 2021. Acceptance: 10 January 2022.

Bouabdellah, Florian, Lessner, Emily, and Benoit, Julien. 2022. The rostral neurovascular system of Tyrannosaurus rex.

Palaeontologia Electronica, 25(1):a3. https://doi.org/10.26879/1178

palaeo-electronica.org/content/2022/3518-t-rex-trigeminal-canals

Copyright: January 2022 Paleontological Society.

This is an open access article distributed under the terms of Attribution-NonCommercial-ShareAlike 4.0 International (CC BY-NC-SA

4.0 ), which permits users to copy and redistribute the material in any medium or format, provided it is not used for commercial purposes and the original author and source are credited, with indications if any changes are made.

creativecommons.org/licenses/by-nc-sa/4.0/ 


\section{INTRODUCTION}

Tyrannosaurus rex is probably the most popular and incidentally best-known theropod dinosaur thanks to a century of uninterrupted research efforts. New technologies and cutting-edge techniques have been used to investigate an unmatched number of aspects of $T$. rex palaeobiology, phylogeny, ontogeny, body mass, intraspecific variability, behaviour, paleoproteomics, paleopathology, neurovasculature, and sensory organs (Erickson et al., 1996; Organ et al., 2008; Schweitzer et al., 2009, 2016; Witmer and Ridgely, 2009; Longrich et al., 2010; DePalma et al., 2013; Parrish et al., 2013; Brusatte and Carr, 2016; Carr, 2020; Woodward et al., 2020; Brown et al., 2021). In 2000, X-ray imaging was applied to the specimen FMNH PR 2081 (also known as "Sue") of Tyrannosaurus rex for the first time by Christopher A. Brochu and colleagues from the Field Museum of Natural History (Brochu, 2000, 2003). The specimen's skull was scanned using computed tomography (CT scanning) to study its internal and external structures in silico. Many subsequent studies applied CT scanning to dinosaur cranial material, focusing mainly on both the braincase and bony labyrinth (Knoll et al., 2006, 2012; Sereno et al., 2007; Witmer and Ridgely, 2009; Neenan et al., 2019; King et al., 2020; Sakagami and Kawabe, 2020). Recently, an increasing number of studies have focused on the rostral neurovascular anatomy of extant (e.g., Witmer et al., 2008; Leitch and Catania, 2012; Porter and Witmer, 2015, 2016; Jones et al., 2019; Lessner et al., 2019; Lessner and Holliday, 2020) and extinct amniote taxa, including therapsids (Benoit et al., 2016a, 2016b, 2017b, 2019; Pusch et al., 2019; Wallace et al., 2019; Pusch et al., 2020; Benoit et al., 2021b; Ekdale and Deméré, 2021), plesiosaurs (Foffa et al., 2014), and archosauromorphs (Lessner et al., 2016; Lessner and Stocker, 2017; SerranoMartínez et al., 2020; Benoit et al., 2021a), including theropod dinosaurs (Ibrahim et al., 2014, 2014; Barker et al., 2017; Cau, 2020; Cerroni et al., 2020; Porter and Witmer, 2020; Kawabe and Hattori, 2021).

The rostral neurovascular system consists of bony canals that housed the trigeminal nerve and some blood vessels (Benoit et al., 2016a; Porter and Witmer, 2020). The trigeminal nerve is the primary somatosensory nerve of the vertebrate head (Watkinson, 1906; Bellairs, 1949; Witmer, 1995; Dubbeldam, 1998; Abdel-Kader et al., 2011; Dakrory, 2011; Leitch and Catania, 2012; Rodella et al., 2012; Schneider et al., 2016; Jones et al., 2019). It stems from the hindbrain, passes through the trigeminal ganglion laterally, and then divides into three main rostral divisions: the ophthalmic division $\left(V_{1}\right)$, the maxillary division $\left(V_{2}\right)$, and the mandibular division $\left(\mathrm{V}_{3}\right)$. The ophthalmic and maxillary divisions transmit sensory inputs from the upper jaw and snout, whereas the mandibular division transmits both motor and sensory signals to and from the lower jaw (Watkinson, 1906; Bellairs, 1949; Dubbeldam, 1998; Abdel-Kader et al., 2011; Dakrory, 2011; Leitch and Catania, 2012; Rodella et al., 2012; Jones et al., 2019). The maxillary division is accompanied by the dorsal alveolar (maxillary) artery and vein and the mandibular division by the ventral alveolar (mandibular) artery and vein (Witmer, 1995; Porter and Witmer, 2015, 2016). These nerves and vessels supply and innervate rostral structures such as the integument, gingiva, and cephalic glands in addition to some specialised sensory structures (Watkinson, 1906; Bellairs, 1949; Witmer, 1995, 1995; Dubbeldam, 1998; Soares, 2002; Sedlmayr, 2002; Abdel-Kader et al., 2011; Dakrory, 2011; Leitch and Catania, 2012; Rodella et al., 2012; Porter et al., 2016; Jones et al., 2019).

Recent research has suggested that access to the rostral neurovascular canals enables the reconstruction of many trigeminal-related soft tissue structures, functions, behaviours, and ecology in extant and extinct archosaurs (Witmer, 1995; Leitch and Catania, 2012; Ibrahim et al., 2014; Barker et al., 2017; Lessner and Stocker, 2017; Porter and Witmer, 2020; Kawabe and Hattori, 2021). In the present study, we use CT scanning to describe the neurovascular canals in rostral cranial elements of Tyrannosaurus rex. We then discuss the evolution of these canals among Sauropsida, as well as previously proposed palaeobiological hypotheses regarding the presence of lips and specialised (i.e., crocodile-like) sensory organs among non-avian theropods.

\section{MATERIAL AND METHODS}

Tyrannosaurus rex specimen FMNH PR 2081 was CT scanned at the Rocketdyne Division of Boeing North America Inc. imaging facility of Chatsworth, CA (see Brochu 2000, 2003 for details). The scanning process generated 1568 coronal slices, each $2 \mathrm{~mm}$ thick. The original CT data is available at Morphosource.org: https://doi.org/ 10.17602/M2/M366912 (Courtesy of: Boeing/Rocketdyne CT-Lab. (c) Field Museum of Natural History. CC BY-NC 4.0. ark:/87602/m4/369673, https:/ /mm.fieldmuseum.org/c1fc8eb7-afa9-4988-b6cf- 
9e258d08f16e). The rostral neurovascular canals and associated structures were segmented and reconstructed digitally in 3D using Avizo 9.0 (FEl VSG, Hillsboro OR, USA) at the Virtual Palaeontology Lab of the Evolutionary Studies Institute (ESI) of the University of the Witwatersrand (Johannesburg, South Africa). Only the right neurovascular canals were segmented, the left side of the skull being damaged and crushed. As this study focuses on the bony canals that transmitted soft tissues actively playing a role in the innervation and nutrition of the surface of facial bones, only the parts of the branches that directly communicate with the external surface of the skull were segmented (Figure 1, Appendix 1, see Benoit et al., 2016a, 2019).

\section{DESCRIPTION}

The three main divisions of the rostral neurovascular system are well preserved in FMNH PR 2081 (Figures 2-5). Like in other reptiles, the rostral

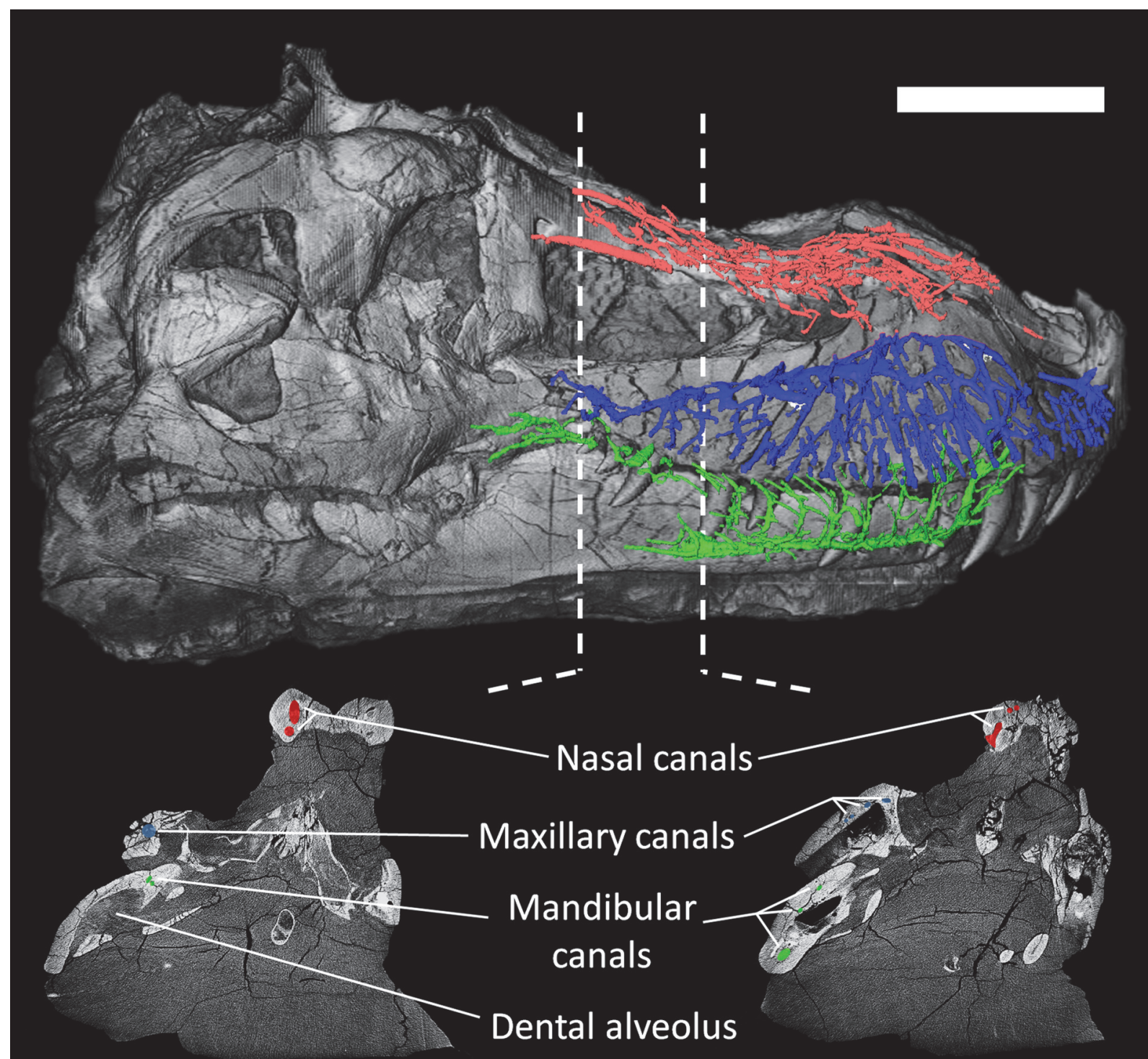

\section{Color code}

\section{Nasal canals}

Maxillary and premaxillary canals

\section{Mandibular canals}

FIGURE 1. The rostral neurovascular canals of Tyrannosaurus rex (FMNH PR 2081) in lateral view (top) and two cross-sections (CT slices, bottom). Scale bar equals $30 \mathrm{~cm}$. 


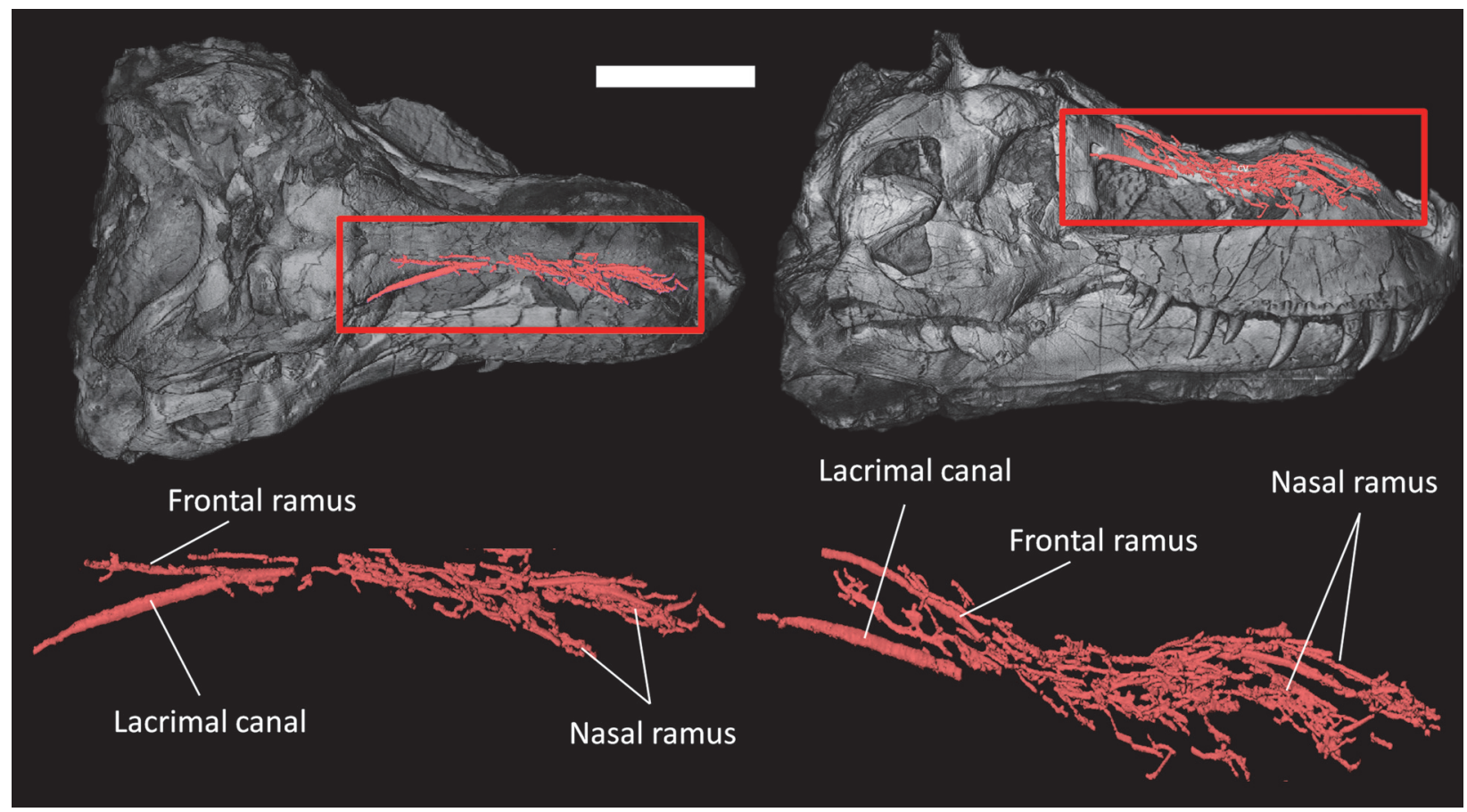

FIGURE 2. Nasal canals of Tyrannosaurus rex (FMNH PR 2081) in dorsal view (left) and lateral view (right). Scale bar equals $30 \mathrm{~cm}$.

neurovascular system is divided into three main branches in Tyrannosaurus: one in the nasal bone containing medial and lateral canals (mostly for the medial and lateral nasal vessels, Figure 2), one in the maxillary bone containing the maxillary division of the trigeminal nerve $\left(V_{2}\right.$, Figure 3$)$, and the last one in the dentary bone containing the mandibular division of the trigeminal nerve $\left(\mathrm{V}_{3}\right.$, Figure 4$)$, the last two of which are accompanied by the dorsal alveolar and mandibular vessels, respectively, (Watkinson, 1906; Bellairs, 1949; Jollie, 1962; Dubbeldam, 1998; Sedlmayr, 2002; Abdel-Kader et al., 2011; Porter et al., 2016; Dakrory, 2011; Leitch and Catania, 2012; Jones et al., 2019).

Contrary to the arrangement in crocodilians (Sedlmayr, 2002; Leitch and Catania, 2012; George and Holliday, 2013; Porter et al., 2016; Lessner and Holliday, 2020), the nasal canal is long and branches into a dense network of canals in Tyrannosaurus (Figure 2). The nasal canal system is divided into a cluster of branches oriented caudally (frontal ramus; Figure 2) and a cluster oriented rostrally (nasal ramus; Figure 2). The frontal ramus is relatively unbranched, directed caudally along the midline of the skull, and likely carried some nasal vessels (Sedlmayr, 2002; Porter et al., 2016; Porter and Witmer, 2020). Rostrally, the nasal ramus runs parallel to the sagittal plane on the nasal bone. The canal splits into many branches rostrally that are grouped into two distinct bundles, a short lateral one and a long medial one. As in modern crocodilians, these bundles likely housed the lateral and medial nasal artery in life (Witmer, 1995; Sedlmayr, 2002; Porter and Witmer, 2015; Porter et al., 2016) and perhaps some branches of the ophthalmic nerve, as has been hypothesised for some therapsids (Benoit et al., $2016,2017 b)$. Some isolated canals run dorsoventrally through the bone and likely housed branches of the nasal vessels and ophthalmic nerve as well (Witmer, 1995; Porter and Witmer, 2015; Cerroni et al., 2020). Unlike in some non-mammalian therapsids (Benoit et al., 2019), the lacrimal canal is wellseparated from the rest of the neurovascular canals.

The maxillary canal (Figure 3 ) runs laterally through the maxilla, dorsal to the tooth row. In modern taxa, the maxillary canal (also known as the superior or dorsal alveolar canal) carries the maxillary division of the trigeminal nerve $\left(\mathrm{V}_{2}\right)$, part of the facial nerve (CN VII; Watkinson, 1906; Bellairs, 1949; Abdel-Kader et al., 2011) and the maxillary (or dorsal alveolar) artery and veins (Porter and Witmer, 2015; Porter et al., 2016). In Tyrannosaurus, the main trunk starts caudomedially, ventral to the orbit, and runs rostrally in a diagonal, rostrodorsal direction. About a dozen smaller canals branch ventrally from the main trunk of the 


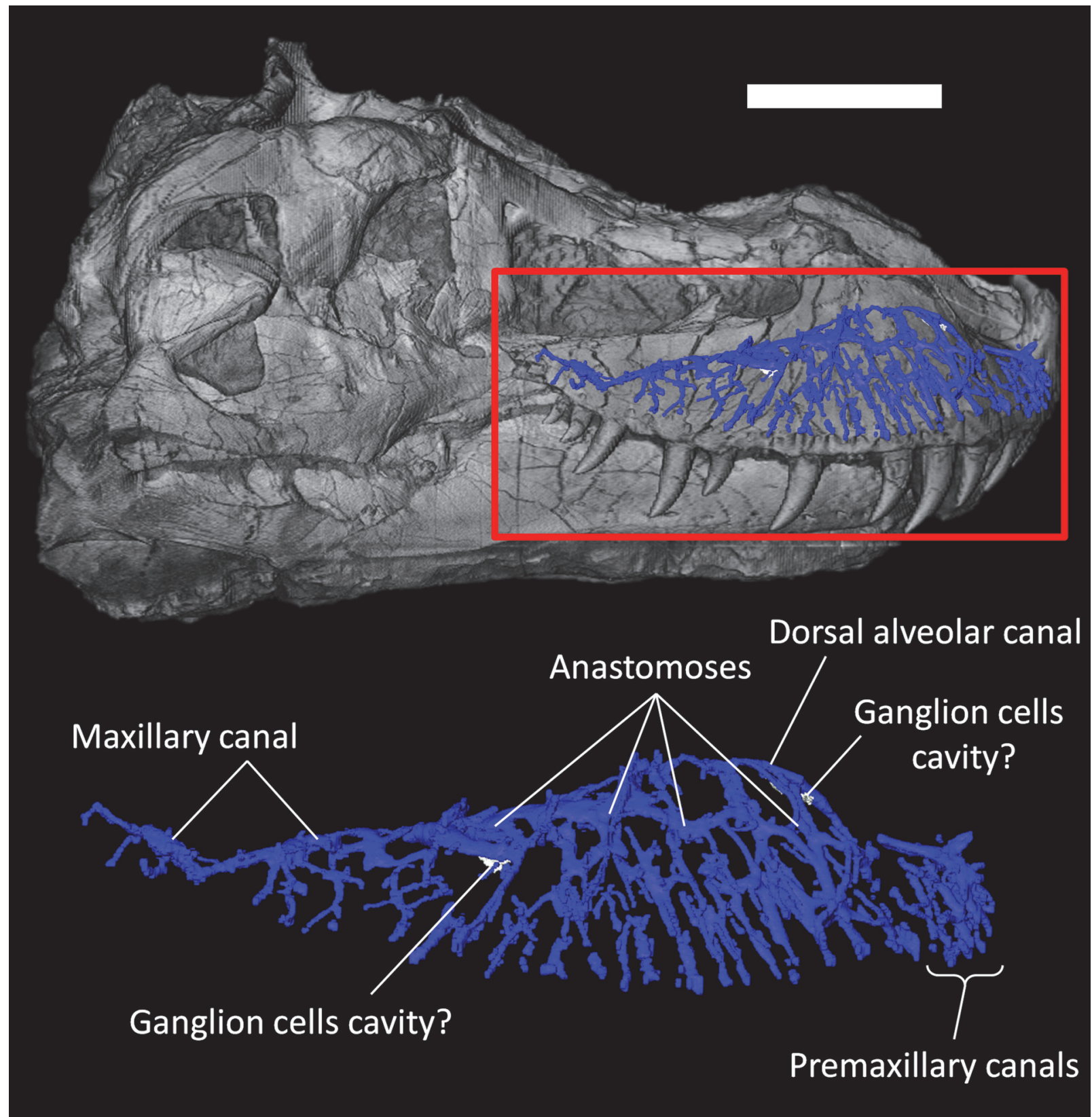

FIGURE 3. Premaxillary canal and canals for the dorsal alveolar (maxillary) vessels and maxillary division of the trigeminal nerve of Tyrannosaurus rex (FMNH PR 2081) in lateral view. Scale bar equals $30 \mathrm{~cm}$.

maxillary canal at regular intervals (Figure 3). These rami are oriented toward the ventral margin of the maxilla and become increasingly elongated and ramified as the maxillary canal progresses rostrally. Their contents likely supplied and innervated the skin through a large number of lateral foramina organised in rostrocaudal rows, as in the majority of non-avian theropods (Brochu, 2003; Dal Sasso et al., 2005; Barker et al., 2017; Kawabe and Hattori, 2021). Some branches are anastomosed, forming a network, as in Neovenator (Barker et al.,
2017). The ventral branches of the maxillary canal in Tyrannosaurus rex are comparatively longer than in most other reptiles (Ibrahim et al., 2014; Porter and Witmer, 2015, 2020; Lessner et al., 2016; Barker et al., 2017; Lessner and Stocker, 2017; Lomax et al., 2019; Lessner and Holliday, 2020). Some medial branches (not figured) innervated and supplied the teeth in their alveoli. The rostral half of the maxillary canal has the longest lateral branches, which are themselves ramified into smaller branches, with many anastomotic con- 


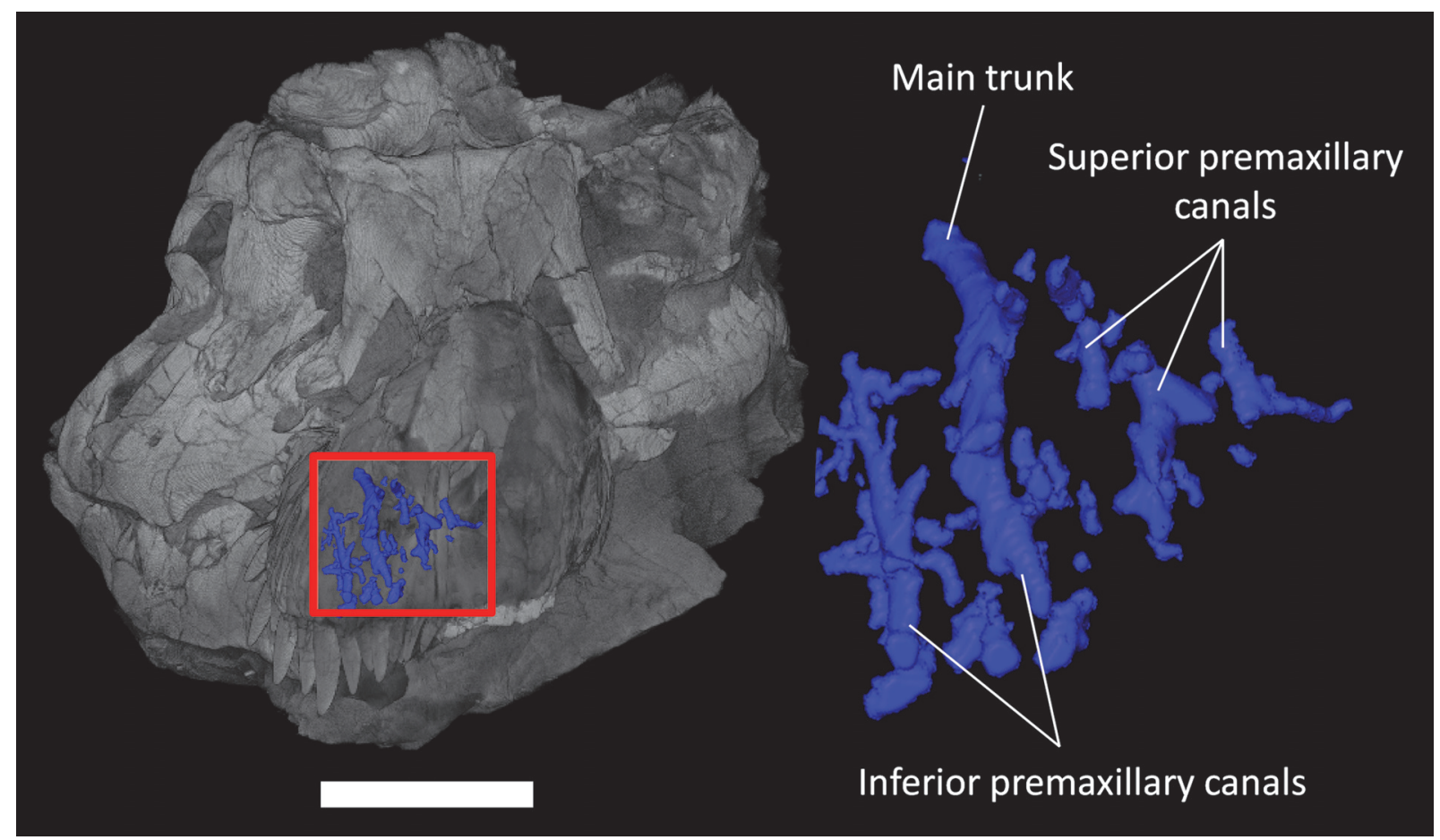

FIGURE 4. Premaxillary canals of Tyrannosaurus rex (FMNH PR 2081) in anterior view. Scale bar equals 30cm.

nections between them, creating a complex network of canals as in extant crocodilians (Leitch and Catania, 2012; George and Holliday, 2013; Lessner and Holliday, 2020). The dorsalmost branch passes dorsal to the replacement teeth rostrally and then bends ventrally. It may have carried the maxillary (or dorsal alveolar) nerve and vessels as in modern sauropsids (Figure 3; Witmer 1995; Porter and Witmer 2015; Porter et al., 2016). Finally, the maxillary canal thickens at two points above the position of maxillary teeth $n^{\circ} 5$ and $n^{\circ} 10$ that may represent spaces to accommodate agglomerated ganglions, as in modern squamates (Figure 3; Abdel-Kader et al., 2011).

The premaxilla is pierced by a small number of isolated canals connecting the oral cavity to the external surface (Figure 4). The canals appear clustered into two branches here referred to as the inferior and superior premaxillary canals (Figure 4; Watkinson, 1906; Bellairs, 1949; Abdel-Kader et al., 2011; Dakrory, 2011). They could have been shared by rami of the ophthalmic and nasopalatine branches of the trigeminal nerve (see discussion). In modern squamates, these nerves are accompanied by subnasal blood vessels (Porter and Witmer, 2015).

The mandibular canal originates in the caudoventral portion of the dentary, and its main trunk runs along the ventral margin of the dentary (Figure 5). In life, it would have carried the ventral-alve- olar nerve $\left(\mathrm{V}_{3}\right)$ and the mandibular (or ventral alveolar) artery (Witmer, 1995; Porter and Witmer, 2015; Kawabe and Hattori, 2021). In Tyrannosaurus, the main trunk of the mandibular canal sends off nine vertical branches toward the upper margin of the dentary (Figure 5). Noticeably, the caudalmost of these dorsal branches travels backwards along the upper margin of the dentary and terminates into a number of foramina on the coronoid process. A similar "backwards running" dorsal branch has also been figured in an ichthyosaur (Lomax et al., 2019). It may have been for a ramus of the mandibular nerve, or the dorsal bifurcation of the mandibular canal for the mandibular artery coming from the skull (Porter and Witmer, 2015; Lessner and Holliday, 2020). The pattern described here in FMNH PR 2081 almost perfectly matches that described by Kawabe and Hattori (2021) for Tyrannosaurus specimen FPDM-V-9767.

\section{DISCUSSION}

\section{Evolution of the Rostral Neurovascular Canals in Sauropsida}

In the absence of an extensive fossil record of soft tissue, studying the rostral neurovascular canals of the trigeminal system, which are responsible for carrying the soft tissues innervating and supplying facial structures and teeth in modern 


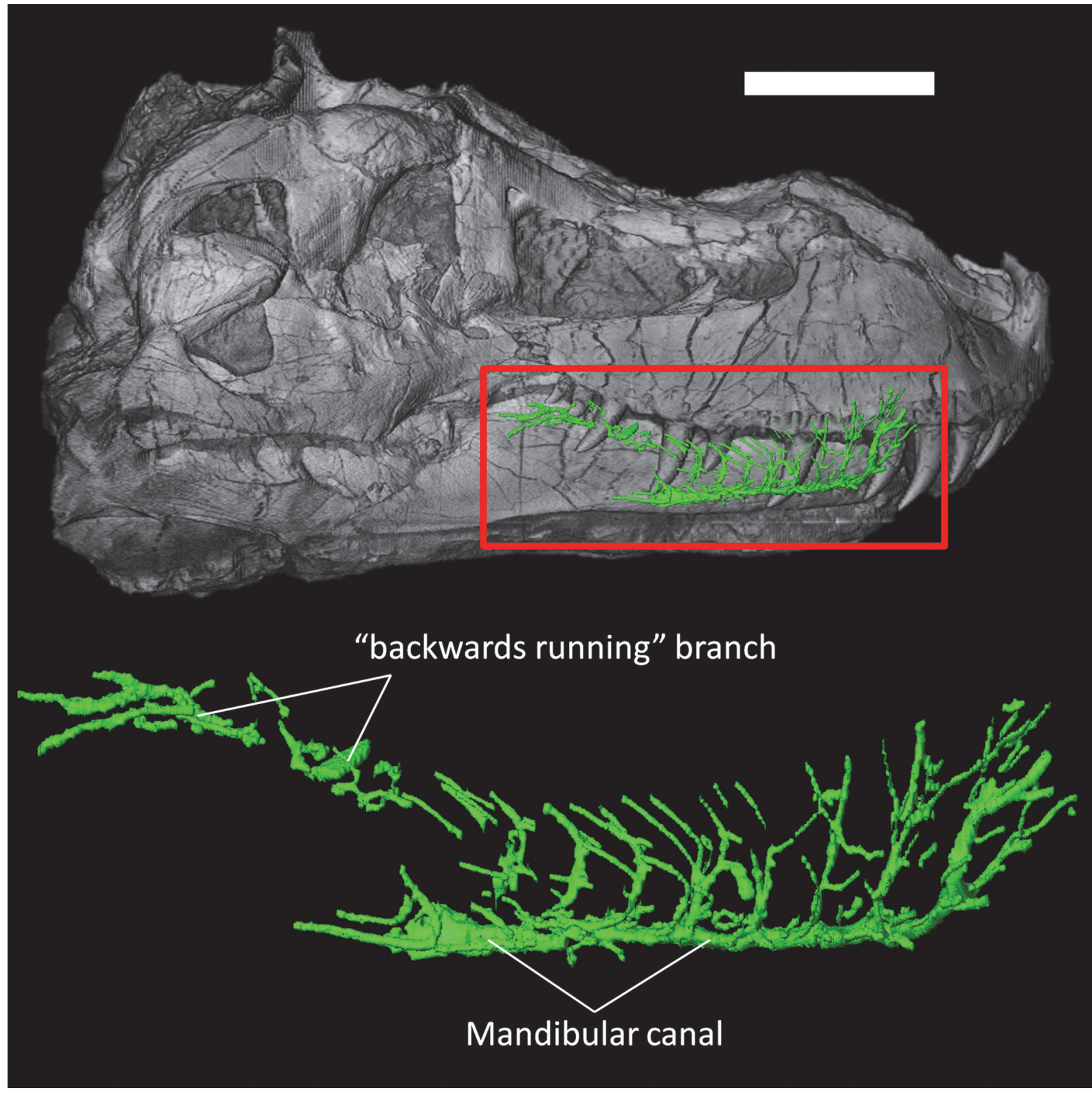

FIGURE 5. Canals for the mandibular vessels and mandibular division of the trigeminal nerve of Tyrannosaurus rex (FMNH PR 2081) in lateral view. Scale bar equals $30 \mathrm{~cm}$.

species, is of paramount importance for palaeobiological reconstructions. Specimen FMNH PR 2081 provides the most complete picture of the rostral neurovascular canals in a theropod dinosaur so far and along with previous studies (e.g., Butler et al., 2012; Ibrahim et al., 2014; Paulina-Carabajal et al., 2016; Barker et al., 2017; Wang et al., 2018; Herne et al., 2019; Cau, 2020; Porter and Witmer, 2020; Kawabe and Hattori 2021), fills an important evolutionary gap that enables discussion and reconstruction of the evolution of the neurovascular system among Sauropsida. To better assess the relevance of the observations made above on $T$. rex, we here provide an overview of the published literature about the rostral neurovascular system of extinct sauropsids. This will help explain where non-avian theropods fit into the big picture of rostral neurovascular evolution and facilitate meaningful comparisons.

The primitive diapsid condition. Benoit et al. (2021a) hypothesised that the maxillary canal (or superior, or dorsal alveolar canal) in Diapsida is primitively long and tubular, runs parallel to the tooth row, and sends off lateral branches at regular intervals towards the supralabial foramina, which are aligned on the dental margin of the maxilla. 
A. Varanus

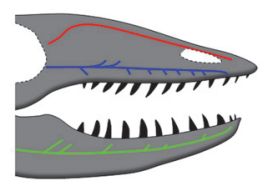

C. Ichthyosauria

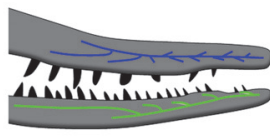

B. Mosasauria

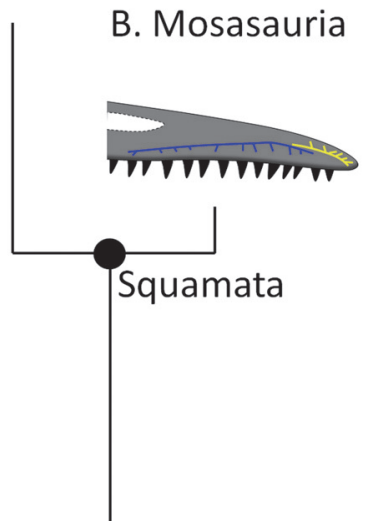

E. Prolacerta

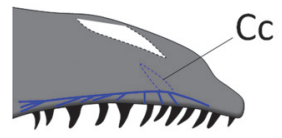

G. Non-theropods
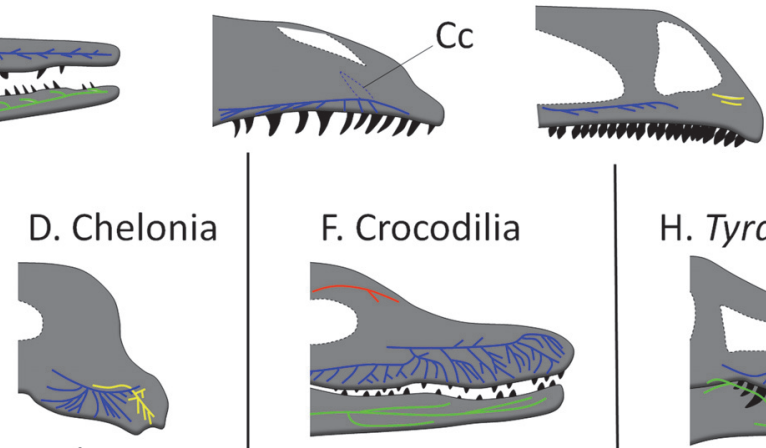

F. Crocodilia

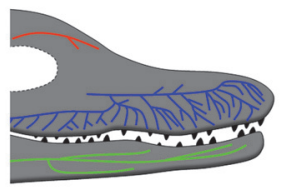

H. Tyrannosaurus

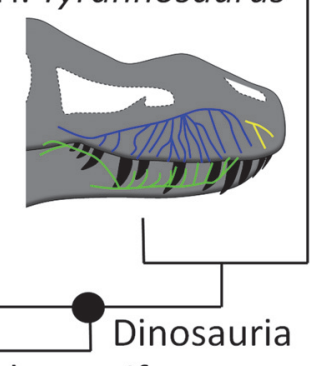

Archosauriformes Archosauromorpha

Archelosauria

Sauropsida

Color code
Ophthalmic nerve Maxillary canals
or nerve
Premaxillary canals
Mandibular canals or nerve

FIGURE 6. Simplified evolution of the rostral neurovascular systems in Sauropsida in lateral view. A, F, and I figure the course of some branches of the trigeminal nerve, whereas B, C, D, E, G, and H figure the canals of the rostral neurovascular system (see text for descriptions and references). Abbreviation: Cc, conical cavity. Color code: Black, teeth; Blue, maxillary canal (or nerve when applicable); Green, mandibular canal (or nerve when applicable); Red, ophthalmic nerve; Yellow, premaxillary canal. Dotted lines represent non-nervous structures (e.g., orbits, nostrils, cranial fenestrae, and conical cavity). Drawings not to scale.

This condition is also present in all modern squamates that have been described so far (Watkinson, 1906; Willard, 1915; Bellairs, 1949; Abdel-Kader et al., 2011; Dakrory, 2011; Porter and Witmer, 2020; Scanferla and Smith, 2020), as well as in the Mosasauria (Bastiaans et al., 2020; Álvarez-Herrera et al., 2020), and Ichthyosauria (Lomax et al., 2019) (Figure 6). The condition is essentially the same for the mandibular canal (or inferior, or ventral alveolar canal), which runs parallel to the tooth row in the dentary bone (Porter and Witmer, 2015; Kawabe and Hattori, 2021; Lessner, 2021). The mandibular canal appears to be very conservative as it shows only minor variations between squamates, crocodylomorphs, non-avian dinosaurs, and birds (Goris, 2011; Porter and Witmer, 2015; Scanferla and Smith, 2020; Kawabe and Hattori, 2021; Lessner, 2021). The maxillary and mandibular canals remain unaltered in snakes and lizards with a venomous bite as venom is carried to the mouth in a system independent of the trigeminal canals (Fry et al., 2009; Goris, 2011; Benoit et al., 2017a). Benoit et al. (2021a) described the presence of a blind, conical cavity dorsal to the main trunk of the maxillary canal in Orovenator and Prolacerta (Figure 6E), but such a cavity appears to be absent in Tyrannosaurus and other derived sauropsids (Porter and Witmer, 2015; Porter et al., 2016; Benoit et al., 2016a, 2018; Lessner et al., 2016; Lomax et al., 2019; Lessner and Holliday, 2020). In Chelonia (Figure 6D), the edentulous condition of the maxilla and premaxilla, and the evolution of a rhamphotheca have modified the structure of the snout, but the plesiomorphic condition of the maxillary canal remains mostly unaltered (Owen, 1866; Albrecht, 1967; Benoit et al., 2018).

Which nerve(s) occupied the premaxillary canals? The canals of the premaxilla show noticeable variations among sauropsids. Unlike the condition in Tyrannosaurus, a distinctly long and ramified premaxillary canal is present in Chelonia that carries vessels and nerves supplying the premaxillary portion of the rhamphotheca and innervating the rostral pores (Winokur and Legler, 1974; Benoit et al., 2018). Although the premaxillary canal is classically interpreted as housing the ophthalmic branch of the trigeminal nerve in extinct 


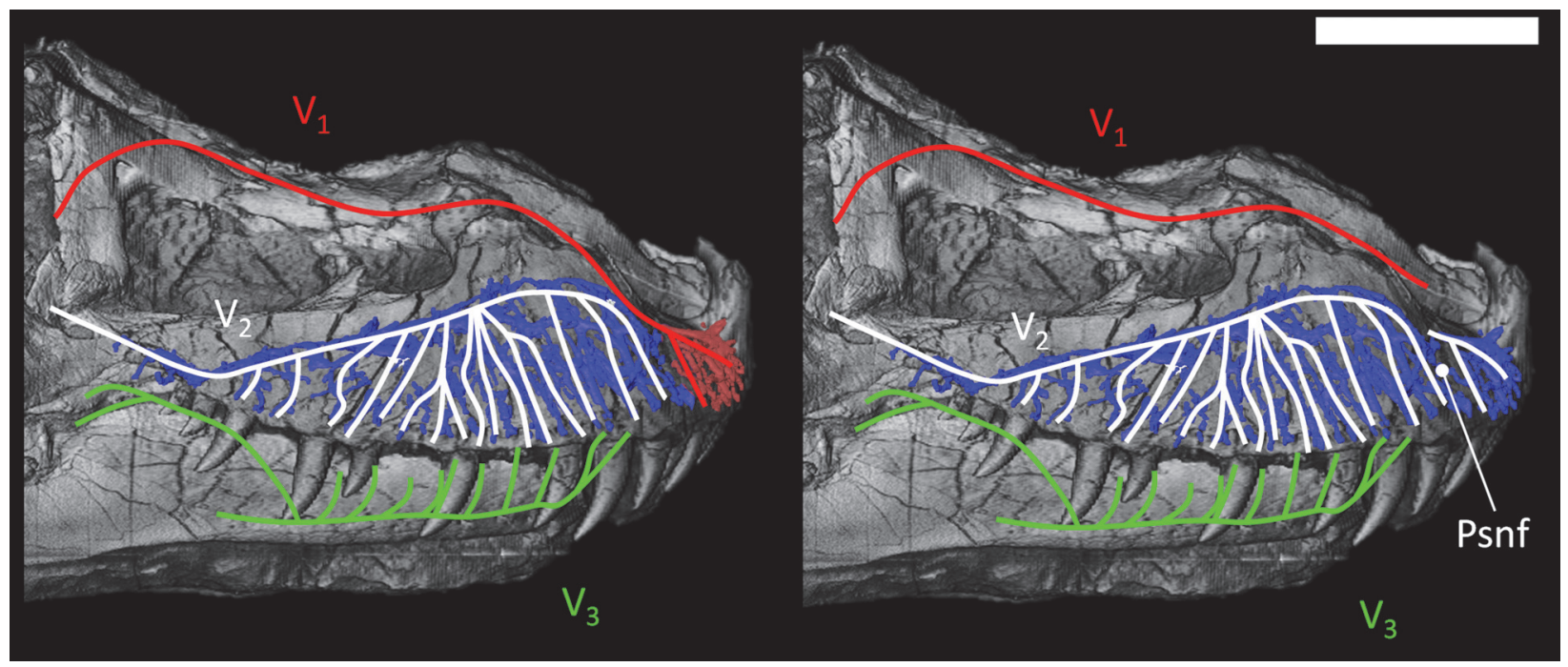

FIGURE 7. Reconstruction of the trigeminal branches pathway in the snout of Tyrannosaurus rex (FMNH PR 2081) in lateral view. Left, dominant ophthalmic branch hypothesis ("bird-like" condition). Right, dominant maxillary branch hypothesis ("reptile-like" condition). Abbreviations: $V_{1}$, Ophthalmic branch; $V_{2}$, Maxillary branch; $V_{3}$, Mandibular branch; Psnf, position of the palatal sub-narial foramen. Scale bar equals $30 \mathrm{~cm}$. Color code same as Figure 6 .

sauropsids (e.g., Sedlmayr, 2002; Foffa et al., 2014; Cau, 2020; Porter and Witmer, 2020), the caudal opening of the premaxillary canal in chelonians is located on the palate and is consequently interpreted as carrying the nasopalatine nerve (a branch of $\mathrm{V}_{2}$ ) and vessels (Owen, 1866; Benoit et al., 2018). The nasopalatine nerve is also responsible for innervating most of the premaxilla in squamates and crocodilians, in which the ophthalmic branch of the trigeminal nerve and corresponding canals are comparatively shorter (Sedlmayr, 2002; Leitch and Catania, 2012; George and Holliday, 2013; Lessner and Holliday, 2020). The ophthalmic nerve nevertheless does reach the premaxilla in these taxa (Bellairs, 1949; Witmer, 1995; Dubbeldam, 1998; Sedlmayr, 2002; Hieronymus, 2019; Lessner and Holliday 2020) and even innervates the medial half of the tentacle in Erpeton tentaculatum (Catania, 2011).

In modern birds (Neornithes), the beak is perforated by a dense network of canals connected to numerous foramina, as is usually the case in beaked tetrapods (Webb, 1957; Berkhoudt, 1979; Baumel et al., 1993; Benoit et al., 2018; Wang et al., 2018); however, the innervation pattern is markedly different from that in chelonians. In most modern birds, the maxillary bone is reduced and as a result, the maxillary canal and supralabial foramina are absent-likely as a result of the evolution of edentulous jaws (Mayr, 2018)-and it appears that the maxillary nerve no longer penetrates the maxilla (Figure 6l), except in Laridae and Anseriformes, which have an enlarged maxilla and in which a few foramina are present (Baumel et al., 1993; Dubbledam et al., 1995; Orosz and Bradshaw, 2007; Mayr, 2018). The ophthalmic nerve, which runs through the enlarged premaxilla in birds, thus becomes the dominant source of nervous flux to the upper beak (Webb, 1957; Gheție et al., 1976; Baumel et al., 1993; Witmer, 1995; Dubbeldam, 1998; Orosz and Bradshaw, 2007; Crole and Soley, 2014; Hieronymus, 2019; Jones et al., 2019). This condition is likely plesiomorphic for Neornithes as the Palaeognathae, Galliformes, and the sister taxon to Galloanserae, Asteriornis, all possess a small maxillary bone with no foramen for the infraorbital branch of the maxillary nerve (Baumel et al., 1993; Mayr, 2018; Field et al., 2020). In contrast, toothed non-neornith birds display a row of supralabial foramina and a maxillary canal (Mayr, 2018).

Given the differences between the Neornithes and non-Neornithes conditions, it is unclear which of the nasopalatine $\left(\mathrm{V}_{2}\right)$ or ophthalmic $\left(\mathrm{V}_{1}\right)$ nerves dominated the premaxillary canals in $T$. rex (Figure 7). A palatal subnarial foramen for possible passage of the nasopalatine nerve has been inconsistently reported in Tyrannosaurus (Carr, 1999; Brochu, 2003; Porter, 2015), and its ventral location would be inconvenient given the more dorsal location of the posterior opening of the premaxillary canals (Figure 7). So, regardless of whether a subnarial foramen is present or not, it appears more likely that the ophthalmic nerve occupied most of 
the premaxillary canals in Tyrannosaurus, as in modern birds.

The maxillary and mandibular canals. The maxillary canal comprises a linear tube running horizontally a distance from the dental margin of the maxilla. The maxillary canal condition in basal Archosauromorpha is the same as in early diapsids and squamates, as exemplified by Prolacerta (Figure 6D; Benoit et al., 2021a). That the maxillary canal condition described by Benoit et al. (2021a) in early diapsids appears mostly unaltered among most Sauropsida supports that a long, tubular, and simple canal branching at regular intervals is the plesiomorphic condition for the clade. In chelonians it sends off a large number of long lateral branches, consistent with the very high number of supralabial foramina that supply the rhamphotheca (Albrecht, 1967; Morhardt, 2009; Benoit et al., 2018). No data is presently available on the maxillary canal of pterosaurs, but given the variation in number and position of their rostral neurovascular foramina (Martill et al., 2021), some departure is expected from the primitive condition described above.

Compared to Prolacerta, the main trunk of the maxillary canal runs a long distance from the ventral margin of the maxilla in crocodiles, Vivaron, Wannia, and most non-avian theropods (Soares, 2002; Leitch and Catania, 2012; Butler et al., 2012; Ibrahim et al., 2014; Lessner et al., 2016; Barker et al., 2017; Lessner and Stocker, 2017; Lessner and Holliday, 2020; Porter and Witmer, 2020; Figure 6). This distance between the main trunk of the maxillary canal and the ventral margin of the maxilla is particularly striking in Tyrannosaurus in which the lateral branches of the maxillary canal occupy the lower third of the surface of the maxilla (Brochu, 2003; Figure 3). This is most likely due to the development of deep dental alveolae (thecodont tooth implantation), as in many archosauriforms (Pinheiro et al., 2016). As the maxillary nerve and vessels have to supply and innervate the dental pulp (in addition to the surface of the maxilla), the position of the main trunk of the maxillary canal has to shift dorsally to follow the base of the tooth sockets. Accordingly, a ventral shift of the mandibular canal can also be inferred on the lower jaw of many archosaurs based on the condition in FMNH PR 2081 (Figure 5), other non-avian dinosaurs (Kawabe and Hattori, 2021), and crocodilians (Lessner, 2021). Some variability in the position of the main trunk of the maxillary and mandibular canals relative to the dental margin of the jaws is thus expected among archosaurs depending on the depth of the alveolae (see e.g., Paulina-Carabajal et al., 2016; Herne et al., 2019; Porter and Witmer, 2020; Kawabe and Hattori, 2021) and the presence of an edentulous beak (Wang et al., 2018).

The maxillary canal has been described and illustrated in only a handful of non-avian dinosaurs (Dal Sasso et al., 2005; Butler et al., 2012; Ibrahim et al., 2014; Lautenschlager et al., 2014; PaulinaCarabajal et al., 2016; Barker et al., 2017; Wang et al., 2018; Porter and Witmer, 2020). The Ornithischia Psittacosaurus, Stegoceras; Fruitadens, and basal Sauropodomorpha Plateosaurus all display a primitively tubular maxillary canal that gives off lateral branches at regular intervals, and the supralabial foramina are organised in a single line parallel to the tooth row, consistent with the primitive sauropsid condition (Figure 6G; Porter, 2015; Porter and Witmer, 2020). The canal of Lesothosaurus displays a similar condition, except that the supralabial foramina are greatly enlarged, perhaps to innervate and supply cheek muscles (Knoll, 2008). Among derived Ornithischia, some Ankylosauria depart from this primitive condition by displaying an enlarged maxillary canal, perhaps acting in conjunction with their nasal passage to act as a heat exchanging mechanism (Porter and Witmer, 2020). In contrast, the ankylosaur Pawpawsaurus displays the primitive condition (Paulina-Carabajal et al., 2016). The maxillary canal of the ornithopod Galleonosaurus matches the primitive condition too, except for the presence of two dorsally directed branches that open anteriorly to the antorbital fenestra (Hernet et al., 2019). A generally simple and plesiomorphically tubular maxillary canal condition in Ornithischia would be consistent with the relatively simple morphology of the mandibular canal figured for Fuikuisaurus, Edmontosaurus, and Triceratops (Kawabe and Hattori, 2021). Strangely enough, Diplodocus shows no evidence of a maxillary canal (Porter and Witmer, 2020), whereas a neonate titanosaur from Argentina displays evidence of some rostral neurovasculature (Kundrát et al., 2020). Data on other sauropodomorphs will be necessary to determine whatthe plesiomorphic condition is for the clade. Dimensions of the foramen for the trigeminal nerve and other palaeoneurological evidence were used to argue against the presence of a trunk in sauropods (Knoll et al., 2006).

The non-avian theropods Spinosaurus, Neovenator, Majungasaurus, and Tyrannosaurus depart from the primitive condition by the large number of supralabial foramina organised in many 
rows instead of one, and the intense branching of their maxillary canal, in which the lateral branches emitted by the main trunk form a dense network of long and interconnected canals directed toward the dental margin of the maxilla (Figure 3; Dal Sasso et al., 2005; Ibrahim et al., 2014; Barker et al., 2017; Porter and Witmer, 2020). Noticeably, the therizinosaurid Erlikosaurus is an exception as it displays the seemingly primitive single row of foramina on the maxilla with a simple, tubular maxillary canal as in Plateosaurus (Lautenschlager et al., 2014). This may be a secondary simplification of the maxillary canal morphology due to the development of an edentulous beak, although the edentulous condition in Limusaurus, Caenagnathasia, and Sapeornis is, in contrast, accompanied by a multiplication of neurovascular canals on the lower jaw (Wang et al., 2018).

\section{The Question of Rostral Sensory Systems in Non-Avian Theropods}

In crocodilians, the high number of branches of the rostral neurovascular system (maxillary, nasal and mandibular canals) and densely foraminiferous snout and lower jaws are associated with the presence of highly sensitive integumentary sensory organs, which sense minute changes in water pressure (Soares, 2002; Leitch and Catania, 2012). Studies of early Crocodyliformes, the phytosaur Wannia, and the rauisuchid Vivaron, however, demonstrate that basal archosauriforms had only few supralabial foramina organised in a single line parallel to the tooth row as in early diapsids and squamates, and that the maxillary canal was simple, tubular, and did not send off as many branches as in modern crocodiles (Soares, 2002; Lessner et al., 2016; Lessner and Stocker, 2017). Additionally, highly sensitive rostral integumentary systems are limited to a few distinct clades of modern birds, such as waterfowl, kiwi, ibises, parrots, and shorebirds, which display specialised tactile-foraging behaviours (e.g., probing, dabbling) in conjunction with a highly ramified trigeminal system and richly foraminiferous beak (Gottschaldt and Lausmann 1974; Berkhoudt, 1979; Gottschaldt, 1985; Cunningham et al., 2010, 2013; Demery et al., 2011; Crole and Soley, 2017; du Toit et al., 2020). Although much work is still required to highlight the numerous specialisations of facial sensitivity in modern archosaurs (Wakimizu and Tsuihiji, 2021), it is safe to state at this stage that the conditions in modern crocodilians and birds is derived for Crocodylomorpha and
Theropoda respectively, and were likely absent at the root of the Archosauriformes clade.

The premaxillary canals of Spinosaurus and Halszkaraptor have also been noted for their intense branching pattern, this time leading to hypotheses of sensing and hunting in an aquatic environment (Cau, 2020). In the mosasaur Taniwhasaurus and plesiosaur Plesiosaurus, the premaxillary canals are enlarged and branched, which suggests improved neurovascular supply at the top of the rostrum (Foffa et al., 2014; Álvarez-Herrera et al., 2020). A similar premaxillary canal pattern has also been found in the supposedly semiaquatic dinosaurs Spinosaurus and Halszkaraptor (Ibrahim et al., 2014; Cau, 2020; see below) but not in ichthyosaurs (Lomax et al., 2019).

It has been repeatedly suggested that the similarities between the rostral neurovascular canal morphology (and snout foramina distribution) between some non-avian theropods and extant crocodilians support that at least some of the former had a crocodile-like facial sensitivity, including Tyrannosaurus (Brazaitis and Watanabe, 2011; Ibrahim et al., 2014; Barker et al., 2017; Carr et al., 2017; Carr, 2020; Kawabe and Hattori, 2021). However, the data reviewed above suggest that a much denser network of neurovascular canals in the snout and lower jaw is more commonly encountered in aquatic or semiaquatic taxa (e.g., Spinosaurus, Halszkaraptor, Plesiosaurus), and taxa that developed a rhamphotheca (e.g., Caenagnathasia) (Foffa et al., 2014; Ibrahim et al., 2014; Wang et al., 2018; Benoit et al., 2018; Cau, 2020; Álvarez-Herrera et al., 2020).

The network of canals in Tyrannosaurus appears simpler (Figures 4, 5) though still more derived than in most ornithischians (Kawabe and Hattori, 2021). Overall, it is reasonable to hypothesise that terrestrial taxa such as Tyrannosaurus, Neovenator, and Erlikosaurus may have had average facial sensitivity for non-edentulous terrestrial theropods, although a quantitative approach on a larger sample of modern and extinct taxa will be necessary to test this hypothesis (Lessner and Holliday, 2021). Noticeably, the above inferences of sensory behaviour in non-avian dinosaurs are made exclusive of trigeminal ganglion data. Osteological correlates of trigeminal ganglion size may be indicative of sensory ability (George and Holliday, 2013) but have not been investigated in conjunction with neurovascular canal branching patterns. Therefore, we also suggest caution in sensory interpretations based just on neurovascular canal and foramina patterns. Finally, the exist- 
ence of a sensory organ of unknown nature is not excluded (Rothschild and Naples, 2017).

Working under the hypothesis that Tyrannosaurus rostral neurovascular canals may not have been for improved sensory function, the high concentration of canals in the snout and lower jaw could have been for some soft tissue structures (e.g., keratinous pads) perhaps involved in thermoregulation or social signaling, as was hypothesised for the Abelisauridae Skorpiovenator (Cerroni et al., 2020) and the therapsid Choerosaurus (Benoit et al., 2016b). For Tyrannosaurus, the social signaling hypothesis would be consistent with the abundant healed bite marks found on the maxilla and dentary (Brown et al., 2021) and the fact that the nasal canal is located within the fused and raised nasal bones, which have been interpreted as a socio-sexual display structure (Gates et al., 2016). Porter (2015) figured the digitally reconstructed maxillary canal of a juvenile specimen of Tyrannosaurus (BMRP 2002.4.1) about 13 years old at age of death (stage 5 in Carr, 2020). This specimen's maxillary canal is not dorsally curved, but runs almost horizontally instead, is a lot less branched, and the vascular network covers a smaller surface as the canal is positioned much more ventrally than in the adult (Porter, 2015). This suggests that the neurovascular network of canals in Tyrannosaurus was subject to profound anatomical changes during ontogeny, unlike that in crocodilians (Leitch and Catania, 2012; Lessner et al., 2019), which is also consistent with a socio-sexual function in adults.

\section{The Question of Lips in Non-Avian Theropods}

Extant squamates all exhibit extensive gingiva, lips, and labial scales that cover the teeth, whereas crocodilians have some gingiva, but their tooth crowns remain exposed (Bellairs, 1949; Witmer, 1995; Soares, 2002; Reisz and Larson, 2016; Paul, 2018). Crocodiles also lack the lubricating labial glands present in squamates (Kochva, 1978). Crocodilian enamel becomes brittle when desiccated (Creech, 2004), so it has been hypothesised that their semiaquatic lifestyle compensates for the absence of physical protection (lips) and a moisturising mechanism (lubricating glands) (Reisz and Larson, 2016; Paul, 2018). A terrestrial lifestyle is expected to increase the rate of dental desiccation and accounts for the presence of lips and glands to protect the enamel in squamates. Accordingly, it is reasonably hypothesised that terrestrial non-avian dinosaurs would have had lips to protect their teeth, at least primitively (Paul, 2018).
Although a fossilised, mummified lip fragment has been reported in one sauropod specimen, the almost ubiquitous presence of a cornified beak in ornithischians and intermeshing teeth in many basal pterosaurs casts some doubt on whether the presence of squamate-like lips was the primitive condition for Dinosauria (Morris, 1970; Hieronymus et al., 2009; Paul, 2018). In non-avian theropods, high dental replacement rates (D'Emic et al., 2019) and the size of the foramen for the glossopharyngeal nerve (IX) in Tarbosaurus and Tyrannosaurus, which is linked to salivary secretion (Saveliev and Alifanov, 2007), both suggest that teeth were quickly replaced and saliva was produced abundantly enough so that the enamel of the teeth could have withstood a dry environment.

Recent phylogenetic analyses based on molecular characters suggest that non-avian dinosaurs are deeply phylogenetically nested between the Chelonia, Crocodilia, and Aves (Schweitzer et al., 2009; Chiari et al., 2012; Crawford et al., 2015) so extant phylogenetic bracketing would support the absence of lips as the most likely condition at the root of the dinosaurian clade (Carr et al., 2017). Taking extinct taxa into account, the repeated evolution of a cornified beak among Archelosauria (e.g., in Chelonia, Pterosauria, Ornithischia, many non-avian Theropoda, and Aves) (Norell et al., 2001; Lautenschlager et al., 2013; Wynd et al., 2020) makes the presence of functionally important, non-redundant facial soft tissue an unlikely plesiomorphic state for this clade. All living reptilian species with lips belong to the Lepidosauria (Soares, 2002; Paul, 2018), thus suggesting that phylogenetic effects have to be taken into account while discussing the evolution of lips amongst Sauropsida. Other, more preliminary studies, suggested various links between the presence of lips and tooth size (Reisz and Larson, 2016), rostral bone texture, and jaw occlusion (Ford, 1997, 2015) with opposing conclusions regarding facial soft tissue reconstructions. Another recent study (Morhardt, 2009) suggested that a lower count of snout foramina in modern reptiles is indicative of extensive facial soft tissue. As the number of snout foramina in non-avian theropods matches that in squamates, the author hypothesised that the latter had lips (Morhardt, 2009); however, the same analysis failed to reconstruct the presence of a beak in the Ornithischia that evidently had one. As such, the question of whether non-avian dinosaurs, and particularly theropods, primitively had lips remains currently unanswered. 
It would be tempting to interpret rostral neurovasculature to infer the presence or absence of lips and gums in extinct taxa; however, this would be premature as data on non-avian theropods are still scarce, and it is currently not possible to demonstrate that the neurovascular canals pattern is a reasonable osteological correlate to facial soft tissue. For instance, we proposed above that accommodating the thecodont dentition within the maxilla and dentary might account for many of the variations observed between squamates and archosauriforms. The proposed hypotheses will have to be addressed in the future as discoveries unfold and more data become available.

\section{CONCLUSION}

In groups such as the non-mammalian synapsids, the systematic study of the rostral neurovascular system linked to the trigeminal canals has improved knowledge of their phylogenetic relationships (Benoit et al., 2021a; Duhamel et al., 2021) and palaeobiology by providing evidence for the evolutionary origin of a rhamphotheca and whiskers, presence of a venomous gland, and tactile social behaviours (Benoit et al., 2016a, 2016b, $2017 a, 2017 b, 2018)$. This overview shows that the rostral neurovascular canals have been described in just a few non-avian dinosaurs, but yet already provide great insight into some crucial aspects of their palaeobiology. Most results are still preliminary and somewhat contradictory, which illustrates how dynamic is the current research incentive for new osteological correlates and innovative ways to reconstruct facial sensitivity and soft tissues in non-avian dinosaurs. A more systematic study of dinosaurian rostral neurovascular canals will most certainly highlight some important clues to their evolutionary success, diversity, behaviour, and the origin of birds.

\section{ACKNOWLEDGEMENTS}

We are indebted to Christopher A. Brochu (University of lowa) and the Field Museum of Natural History for making the CT scan of FMNH PR 2081 publicly available. F.B. thanks the Region of Nouvelle Aquitaine for providing funding for travel to South Africa. E.J.L. thanks the University of Missouri for funding research and travel. J.B. thanks the DST-NRF Centre of Excellence in Palaeosciences (CoE in Palaeosciences, GENUS) for its financial support.

\section{REFERENCES}

Abdel-Kader, T.G., Ali, R.S., and Ibrahim, N.M. 2011. The cranial nerves of Mabuya quinquetaeniata III: Nervus trigeminus. Life Science Journal, 8:650-669.

Albrecht, P.W. 1967. The cranial arteries and cranial arterial foramina of the turtle genera Chrysemys, Sternotherus, and Trionyx: a comparative study with analysis of possible evolutionary implications. Tulane Studies in Zoology, 14:81-99.

Álvarez-Herrera, G., Agnolin, F., and Novas, F. 2020. A rostral neurovascular system in the mosasaur Taniwhasaurus antarcticus. The Science of Nature, 107:19. https://doi.org/ 10.1007/s00114-020-01677-y

Barker, C.T., Naish, D., Newham, E., Katsamenis, O.L., and Dyke, G. 2017. Complex neuroanatomy in the rostrum of the Isle of Wight theropod Neovenator salerii. Scientific Reports, 7:3749. https://doi.org/10.1038/s41598-017-03671-3

Bastiaans, D., Kroll, J.J.F., Cornelissen, D., Jagt, J.W.M., and Schulp, A.S. 2020. Cranial palaeopathologies in a Late Cretaceous mosasaur from the Netherlands. Cretaceous Research, 112:104425. https://doi.org/10.1016/j.cretres.2020.104425

Baumel, J.J. 1993. Handbook of Avian Anatomy: Nomina Anatomica Avium, 2nd ed. Publications of the Nuttall Ornithological Club no. 23, Cambridge, Massachusetts.

Bellairs, A.D. 1949. Observations on the snout of Varanus, and a comparison with that of other lizards and snakes. Journal of Anatomy, 83:116-146 + 1 plate.

Benoit, J., Manger, P.R., and Rubidge, B.S. 2016a. Palaeoneurological clues to the evolution of defining mammalian soft tissue traits. Scientific Reports, 6:25604.

https://doi.org/10.1038/srep25604 
Benoit, J., Manger, P.R., Fernandez, V., and Rubidge, B.S. 2016b. Cranial bosses of Choerosaurus dejageri (Therapsida, Therocephalia): earliest evidence of cranial display structures in eutheriodonts. PLoS ONE 11:e0161457. https://doi.org/10.1371/journal.pone.0161457

Benoit, J., Norton, L.A., Manger, P.R., and Rubidge, B.S. 2017a. Reappraisal of the envenoming capacity of Euchambersia mirabilis (Therapsida, Therocephalia) using $\mu C T$-scanning techniques. PLoS ONE, 12:e0172047. https://doi.org/10.1371/journal.pone.0172047

Benoit, J., Manger, P.R., Norton, L., Fernandez, V., and Rubidge, B.S. 2017b. Synchrotron scanning reveals the palaeoneurology of the head-butting Moschops capensis (Therapsida, Dinocephalia). PeerJ, 5:e3496. https://doi.org/10.7717/peerj.3496

Benoit, J., Angielczyk, K.D., Miyamae, J.A., Manger, P., Fernandez, V., and Rubidge, B.S. 2018. Evolution of facial innervation in anomodont therapsids (Synapsida): insights from X-ray computerized microtomography. Journal of Morphology, 279:673-701. https://doi.org/10.1002/jmor.20804

Benoit, J., Ruf, I., Miyamae, J.A., Fernandez, V., Rodrigues, P.G., and Rubidge, B.S. 2019. The Evolution of the maxillary canal in Probainognathia (Cynodontia, Synapsida): reassessment of the homology of the infraorbital foramen in mammalian ancestors. Journal of Mammalian Evolution, 27:329-348. https://doi.org/10.1007/s10914-019-09467-8

Benoit, J., Ford, D., Miyamae, J., and Ruf, I. 2021a. Can maxillary canal morphology inform varanopid phylogenetic affinities? Acta Palaeontologica Polonica, 66:389-393. https://doi.org/10.4202/app.00816.2020

Benoit, J., Kruger, A., Jirah, S., Fernandez, V., and Rubidge, B.S. 2021b. Palaeoneurology and palaeobiology of the dinocephalian Anteosaurus magnificus. Acta Palaeontologica Polonica, 66:29-39. https://doi.org/10.4202/app.00800.2020

Berkhoudt, H. 1979. The morphology and distribution of cutaneous mechanoreceptors (Herbst and Grandry corpuscles) in bill and tongue of the mallard (Anas platyrhynchos L.). Netherlands Journal of Zoology, 30:1-34.

Brazaitis, P. and Watanabe, M.E. 2011. Crocodilian behaviour: a window to dinosaur behaviour? Historical Biology, 23:73-90. https://doi.org/10.1080/08912963.2011.560723

Brochu, C.A. 2000. A digitally-rendered endocast for Tyrannosaurus rex. Journal of Vertebrate Paleontology, 20:1-6. https://doi.org/10.1671/0272-4634(2000)020[0001:ADREFT]2.0.CO;2

Brochu, C.A. 2003. Osteology of Tyrannosaurus rex: insights from a nearly complete skeleton and high-resolution computed tomographic analysis of the skull. Journal of Vertebrate Paleontology, 22:1-138. https://doi.org/10.1080/02724634.2003.10010947

Brown, C.M., Currie, P.J., and Therrien, F. 2021 (online). Intraspecific facial bite marks in tyrannosaurids provide insight into sexual maturity and evolution of bird-like intersexual display. Paleobiology. https://doi.org/10.1017/pab.2021.29

Brusatte, S.L. and Carr, T.D. 2016. The phylogeny and evolutionary history of tyrannosauroid dinosaurs. Scientific Reports, 6:20252. https://doi.org/10.1038/srep20252

Butler, R.J., Porro, L.B., Galton, P.M., and Chiappe, L.M. 2012. Anatomy and cranial functional morphology of the small-bodied dinosaur Fruitadens haagarorum from the Upper Jurassic of the USA. PLoS ONE, 7(4):e31556. https://doi.org/10.1371/journal.pone.0031556

Carr, T.D. 1999. Craniofacial ontogeny in Tyrannosauridae (Dinosauria: Coelurosauria). Journal of Vertebrate Paleontology, 19:497-520. https://doi.org/10.1080/02724634.1999.10011161

Carr, T.D. 2020. A high-resolution growth series of Tyrannosaurus rex obtained from multiple lines of evidence. PeerJ, 8:e9192. https://doi.org/10.7717/peerj.9192

Carr, T.D., Varricchio, D.J., Sedlmayr, J.C., Roberts, E.M., and Moore, J.R. 2017. A new tyrannosaur with evidence for anagenesis and crocodile-like facial sensory system. Scientific Reports, 7:44942. https://doi.org/10.1038/srep44942

Catania, K.C. 2011. The brain and behavior of the tentacled snake. Annals of the New York Academy of Sciences, 1225:83-89. https://doi.org/10.1111/j.1749-6632.2011.05959.x

Cau, A. 2020. The body plan of Halszkaraptor escuilliei (Dinosauria, Theropoda) is not a transitional form along the evolution of dromaeosaurid hypercarnivory. PeerJ, 8:e8672. https://doi.org/10.7717/peerj.8672

Cerroni, M.A., Canale, J.I., Novas, F.E., and Paulina-Carabajal, A. 2020 (online). An exceptional neurovascular system in abelisaurid theropod skull: new evidence from Skorpiovenator bustingorryi. Journal of Anatomy, 240:13258. https://doi.org/10.1111/joa.13258 
Chiari, Y., Cahais, V., Galtier, N., and Delsuc, F. 2012. Phylogenomic analyses support the position of turtles as the sister group of birds and crocodiles (Archosauria). BMC Biology, 10:65. https://doi.org/10.1186/1741-7007-10-65

Crawford, N.G., Parham, J.F., Sellas, A.B., Faircloth, B.C., Glenn, T.C., Papenfuss, T.J., Henderson, J.B., Hansen, M.H., and Simison, W.B. 2015. A phylogenomic analysis of turtles. Molecular Phylogenetics and Evolution, 83:250-257. https://doi.org/10.1016/j.ympev.2014.10.021

Creech, J.E. 2004. Phylogenetic character analysis of crocodylian enamel microstructure and its relevance to biomechanical performance. Unpublished Master's Dissertation, Florida State University, Tallahassee, Florida.

Crole, M.R. and Soley, J.T. 2014. Comparative morphology, morphometry and distribution pattern of the trigeminal nerve branches supplying the bill tip in the ostrich (Struthio camelus) and emu (Dromaius novaehollandiae). Acta Zoologica, 97:19-59. https://doi.org/10.1111/azo.12104

Crole, M.R. and Soley J.T. 2017. Bony pits in the ostrich (Struthio camelus) and emu (Dromaius novaehollandiae) bill tip. The Anatomical Record, 300:1705-1715. https://doi.org/10.1002/ar.23594

Cunningham, S.J., Alley, M.R., Castro, I., Potter, M.A., Cunningham, M., and Pyne, M.J. 2010. Bill morphology of ibises suggests a remote-tactile sensory system for prey detection. The Auk, 127:308-316. https://doi.org/10.1525/auk.2009.09117

Cunningham, S.J., Corfield, J.R., Iwaniuk, A.N., Castro, I., Alley, M.R., Birkhead, T.R., and Parsons, S. 2013. The anatomy of the bill tip of kiwi and associated somatosensory regions of the brain: comparisons with shorebirds. PLoS ONE, 8:e80036. https://doi.org/10.1371/journal.pone.0080036

Dakrory, A.I. 2011. Anatomical study on the cranial nerves of the spiny tail lizard Uromastyx aegyptius (Squamata - Lacertilia - Agamidae). II- nervus facialis. Journal of the EgyptianGerman Society of Zoology, 63:99-129.

Dal Sasso, C., Maganuco, S., Buffetaut, E., and Mendez, M.A. 2005. New information on the skull of the enigmatic theropod Spinosaurus, with remarks on its size and affinities. Journal of Vertebrate Paleontology, 25:888-896. https://doi.org/10.1671/0272-4634(2005)025[0888:NIOTSO]2.0.CO;2

Demery, Z.P., Chappell, J., and Martin, G.R. 2011. Vision, touch and object manipulation in Senegal parrots Poicephalus senegalus. Proceedings of the Royal Society B: Biological Sciences, 278:3687-3693. https://doi.org/10.1098/rspb.2011.0374

D'Emic, M.D., O'Connor, P.M., Pascucci, T.R., Gavras, J.N., Mardakhayava, E., and Lund, E.K. 2019. Evolution of high tooth replacement rates in theropod dinosaurs. PLoS ONE 14:e0224734. https://doi.org/10.1371/journal.pone.0224734

DePalma, R.A., Burnham, D.A., Martin, L.D., Rothschild, B.M., and Larson, P.L. 2013. Physical evidence of predatory behavior in Tyrannosaurus rex. Proceedings of the National Academy of Sciences, 110:12560-12564. https://doi.org/10.1073/pnas.1216534110

Dubbeldam, J.L. 1998. The sensory trigeminal system in birds: input, organization and effects of peripheral damage. A review. Archives of Physiology and Biochemistry, 106:338-345.

Dubbeldam, J.L., De Bakker, M.A.G., and Bout, R.G. 1995. The composition of trigeminal nerve branches in normal adult chickens and after debeaking at different ages. Journal of Anatomy, 186:619-627.

Duhamel, A., Benoit, J., Rubidge, B.S., and Liu, J. 2021. A re-assessment of the oldest therapsid Raranimus confirms its status as a basal member of the clade and fills Olson's gap. The Science of Nature, 108:26. https://doi.org/10.1007/s00114-021-01736-y

du Toit, C.J., Chinsamy, A., and Cunningham, S.J. 2020. Cretaceous origins of the vibrotactile bill-tip organ in birds. Proceedings. Biological Sciences, 287:20202322. https://doi.org/10.1098/rspb.2020.2322

Ekdale, E.G. and Deméré, T.A. 2021. Neurovascular evidence for a co-occurrence of teeth and baleen in an Oligocene mysticete and the transition to filter-feeding in baleen whales. Zoological Journal of the Linnean Society, zlab017. https://doi.org/10.1093/zoolinnean/zlab017

Erickson, G.M., Kirk, S.D.V., Su, J., Levenston, M.E., Caler, W.E., and Carter, D.R. 1996. Biteforce estimation for Tyrannosaurus rex from tooth-marked bones. Nature, 382:706-708. https://doi.org/10.1038/382706a0 
Field, D.J., Benito, J., Chen, A., Jagt, J.W.M., and Ksepka, D.T. 2020. Late Cretaceous neornithine from Europe illuminates the origins of crown birds. Nature, 579:397-401. https://doi.org/10.1038/s41586-020-2096-0

Foffa, D., Sassoon, J., Cuff, A.R., Mavrogordato, M.N., and Benton, M.J. 2014. Complex rostral neurovascular system in a giant pliosaur. Naturwissenschaften, 101:453-456. https://doi.org/10.1007/s00114-014-1173-3

Ford, T.L. 1997. Did theropods have lizard lips? Southwest Paleontological SymposiumProceedings, Mesa Southwest Museum, Arizona, p. 65-78.

Ford, T.L. 2015. Tactile faced theropods. 75th annual meeting of the Society of Vertebrate Paleontology, Meeting Program \& Abstracts, Dallas, Texas, p. 125.

Fry, B.G., Wroe, S., Teeuwisse, W., van Osch, M.J.P., Moreno, K., Ingle, J., McHenry, C., Ferrara, T., Clausen, P., Scheib, H., Winter, K.L., Greisman, L., Roelants, K., van der Weerd, L., Clemente, C.J., Giannakis, E., Hodgson, W.C., Luz, S., Martelli, P., Krishnasamy, K., Kochva, E., Kwok, H.F., Scanlon, D., Karas, J., Citron, D.M., Goldstein, E.J.C., Mcnaughtan, J.E., and Norman, J.A. 2009. A central role for venom in predation by Varanus komodoensis (Komodo Dragon) and the extinct giant Varanus (Megalania) priscus. Proceedings of the National Academy of Sciences, 106:8969-8974. https://doi.org/10.1073/pnas.0810883106

Gates, T.A., Organ, C., and Zanno, L.E. 2016. Bony cranial ornamentation linked to rapid evolution of gigantic theropod dinosaurs. Nature Communications, 7:12931. https://doi.org/10.1038/ncomms12931

George, I.D. and Holliday, C.M. 2013. Trigeminal nerve morphology in Alligator mississippiensis and its significance for crocodyliform facial sensation and evolution. Anatomical Record, 296:670-680. https://doi.org/10.1002/ar.22666

Gheție, V., Chitescu, St., Cotofan, V., and Hillebrand, V. 1976. Anatomical Atlas of Domestic Birds. Editura Academiei Republicii Socialiste Romania, București.

Goris, R.C. 2011. Infrared organs of snakes: an integral part of vision. Journal of Herpetology, 45:2-14. https://doi.org/10.1670/10-238.1

Gottschaldt, K.M. 1985. Structure and function of avian somatosensory receptors. Form and Function in Birds, 3:375-461.

Gottschaldt, K.M. and Lausmann, S. 1974. The peripheral morphological basis of tactile sensibility in the beak of geese. Cell and Tissue Research, 153:477-496. https://doi.org/10.1007/BF00231542

Herne, M.C., Nair, J.P., Evans, A.R., and Tait, A.M. 2019. New small-bodied ornithopods (Dinosauria, Neornithischia) from the Early Cretaceous Wonthaggi Formation (Strzelecki Group) of the Australian-Antarctic rift system, with revision of Qantassaurus intrepidus Rich and Vickers-Rich, 1999. Journal of Paleontology, 93:543-584. https://doi.org/10.1017/jpa.2018.95

Hieronymus, T.L. 2019. Comparative anatomy and physiology of chemical senses in aquatic birds, p. 83-94. In Thewissen, J.G.M.H. and Nummela, S. (eds.), Sensory Evolution on the Threshold. University of California Press, Berkeley.

Hieronymus, T.L., Witmer, L.M., Tanke, D.H., and Currie, P.J. 2009. The facial integument of centrosaurine ceratopsids: morphological and histological correlates of novel skin structures. The Anatomical Record, 292:1370-1396. https://doi.org/10.1002/ar.20985

Ibrahim, N., Sereno, P.C., Dal Sasso, C., Maganuco, S., Fabbri, M., Martill, D.M., Zouhri, S., Myhrvold, N., and lurino, D.A. 2014. Semiaquatic adaptations in a giant predatory dinosaur. Science, 345:1613-1616. https://doi.org/10.1126/science.1258750

Jollie, M. 1962. Chordate Morphology. Reinhold Publishing Corporation, New York.

Jones, M.E.H., Button, D.J., Barrett, P.M., and Porro, L.B. 2019. Digital dissection of the head of the rock dove (Columba livia) using contrast-enhanced computed tomography. Zoological Letters, 5:17. https://doi.org/10.1186/s40851-019-0129-z

Kawabe, S. and Hattori, S. 2021 (online). Complex neurovascular system in the dentary of Tyrannosaurus. Historical Biology, 34. https://doi.org/10.1080/08912963.2021.1965137

King, J.L., Sipla, J.S., Georgi, J.A., Balanoff, A.M., and Neenan, J.M. 2020. The endocranium and trophic ecology of Velociraptor mongoliensis. Journal of Anatomy, 237:861-869. https:// doi.org/10.1111/joa.13253

Knoll, F. 2008. Buccal soft anatomy in Lesothosaurus (Dinosauria: Ornithischia). Neues Jahrbuch für Geologie und Paläontologie - Abhandlungen, 248:355-364. https://doi.org/ 10.1127/0077-7749/2008/0248-0355 
Knoll, F., Galton, P.M., and López-Antoñanzas, R. 2006. Paleoneurological evidence against a proboscis in the sauropod dinosaur Diplodocus. Geobios, 39:215-221. https://doi.org/10.1016/j.geobios.2004.11.005

Knoll, F., Witmer, L.M., Ortega, F., Ridgely, R.C., and Schwarz-Wings, D. 2012. The braincase of the basal sauropod dinosaur Spinophorosaurus and 3D reconstructions of the cranial endocast and inner ear. PLoS ONE, 7:e30060. https://doi.org/10.1371/journal.pone.0030060

Kochva, E. 1978. Oral glands of Reptilia, p. 43-161. In Gans, C. and Gans, K.A. (eds.), Biology of Reptilia, vol. 8. Academic Press, London and New York.

Kundrát, M., Coria, R.A., Manning, T.W., Snitting, D., Chiappe, L.M., Nudds, J., and Ahlberg, P.E. 2020. Specialized craniofacial anatomy of a titanosaurian embryo from Argentina. Current Biology, 30:4263-4269. https://doi.org/10.1016/j.cub.2020.07.091

Lautenschlager, S., Witmer, L.M., Altangerel, P., and Rayfield, E.J. 2013. Edentulism, beaks, and biomechanical innovations in the evolution of theropod dinosaurs. Proceedings of the National Academy of Sciences, 110:20657-20662. https://doi.org/10.1073/pnas.1310711110

Lautenschlager, S., Witmer, L.M., Altangerel, P., Zanno, L.E., and Rayfield, E.J. 2014. Cranial anatomy of Erlikosaurus andrewsi (Dinosauria, Therizinosauria): new insights based on digital reconstruction. Journal of Vertebrate Paleontology, 34:1263-1291. https://doi.org/10.1080/02724634.2014.874529

Leitch, D.B. and Catania, K.C. 2012. Structure, innervation and response properties of integumentary sensory organs in crocodilians. Journal of Experimental Biology, 215:42174230. https://doi.org/10.1242/jeb.076836

Lessner, E.J. 2021. Quantifying neurovascular canal branching patterns reveals a shared crocodylian arrangement. Journal of Morphology, 282:185-204. https://doi.org/10.1002/jmor.21295

Lessner, E.J. and Holliday, C.M. 2021. Limited potential for trigeminal-innervated sensory behaviors among dinosaurs. The Society of Vertebrate Paleontology 81st Annual Meeting Abstract Book, online, p. 169-170.

Lessner, E.J. and Holliday, C.M. 2020 (online). A 3D ontogenetic atlas of Alligator mississippiensis cranial nerves and their significance for comparative neurology of reptiles. Anatomical Record, 305. https://doi.org/10.1002/ar.24550

Lessner, E.J. and Stocker, M.R. 2017. Archosauriform endocranial morphology and osteological evidence for semiaquatic sensory adaptations in phytosaurs. Journal of Anatomy, 231:655664. https://doi.org/10.1111/joa.12668

Lessner, E.J., Stocker, M.R., Smith, N.D., Turner, A.H., Irmis, R.B., and Nesbitt, S.J. 2016. A new rauisuchid (Archosauria, Pseudosuchia) from the Upper Triassic (Norian) of New Mexico increases the diversity and temporal range of the clade. PeerJ, 4:e2336. https://doi.org/10.7717/peerj.2336

Lessner, E.J., Gant, C.A., Hieronymus, T.L., Vickaryous, M.K., and Holliday, C.M. 2019. Anatomy and ontogeny of the mandibular symphysis in Alligator mississippiensis. The Anatomical Record, 302:1696-1708. https://doi.org/10.1002/ar.24116

Lomax, D.R., Porro, L.B., and Larkin, N.R. 2019. Descriptive anatomy of the largest known specimen of Protoichthyosaurus prostaxalis (Reptilia: Ichthyosauria) including computed tomography and digital reconstruction of a three-dimensional skull. PeerJ, 7:e6112. https://doi.org/10.7717/peerj.6112

Longrich, N.R., Horner, J.R., Erickson, G.M., and Currie, P.J. 2010. Cannibalism in Tyrannosaurus rex. PLoS ONE, 5:e13419. https://doi.org/10.1371/journal.pone.0013419

Martill, D.M., Smith, R.E., Longrich, N., and Brown, J. 2021. Evidence for tactile foraging in pterosaurs: a sensitive tip to the beak of Lonchodraco giganteus (Pterosauria, Lonchodectidae) from the Upper Cretaceous of southern England. Cretaceous Research, 117:104637. https://doi.org/10.1016/j.cretres.2020.104637

Mayr, G. 2018. Comparative morphology of the avian maxillary bone (os maxillare) based on an examination of macerated juvenile skeletons. Acta Zoologica, 101:24-38. https://doi.org/10.1111/azo.12268

Morhardt, A.C. 2009. Dinosaur smiles: do the texture and morphology of the premaxilla, maxilla, and dentary bones of sauropsids provide osteological correlates for inferring extra-oral structures reliably in dinosaurs? Unpublished Master's dissertation, Western Illinois University, Macomb.

Morris, W.J. 1970. Hadrosaurian dinosaur bills - morphology and function. Los Angeles County Museum, Contributions in Science, 193:1-14. 
Neenan, J.M., Chapelle, K.E.J., Fernandez, V., and Choiniere, J.N. 2019. Ontogeny of the Massospondylus labyrinth: implications for locomotory shifts in a basal sauropodomorph dinosaur. Palaeontology, 62:255-265. https://doi.org/10.1111/pala.12400

Norell, M.A., Makovicky, P.J., and Currie, P.J. 2001. The beaks of ostrich dinosaurs. Nature, 412:873-874. https://doi.org/10.1038/35091139

Organ, C.L., Schweitzer, M.H., Zheng, W., Freimark, L.M., Cantley, L.C., and Asara, J.M. 2008. Molecular phylogenetics of Mastodon and Tyrannosaurus rex. Science, 320:499-499. https://doi.org/10.1126/science.1154284

Orosz, S.E. and Bradshaw, G.A. 2007. Avian neuroanatomy revisited: from clinical principles to avian cognition. Veterinary Clinics of North America: Exotic Animal Practice, 10:775-802. https://doi.org/10.1016/j.cvex.2007.06.001

Owen, R. 1866. On the Anatomy of Vertebrates Vol. 1: Fishes and Reptiles. Longmans, Green and Company, London.

Parrish, J.M., Molnar, R.E., Currie, P.J., and Koppelhus, E.B. 2013. Tyrannosaurid Paleobiology. Indiana University Press, Bloomington.

Paul, G.S. 2018. Nonornithischian dinosaurs did too have lips, probably big lips, here's why. Prehistoric Times, 127:44-49.

Paulina-Carabajal, A., Lee, Y.-N., Jacobs, L.L., and Iwaniuk, A. 2016. Endocranial morphology of the primitive nodosaurid dinosaur Pawpawsaurus campbelli from the Early Cretaceous of North America. PLoS ONE, 11(3):e0150845. https://doi.org/10.1371/journal.pone.0150845

Pinheiro, F.L., França, M.A.G., Lacerda, M.B., Butler, R.J., and Schultz, C.L. 2016. An exceptional fossil skull from South America and the origins of the archosauriform radiation. Scientific Reports, 6:22817. https://doi.org/10.1038/srep22817

Porter, W.R. 2015. Physiological implications of dinosaur cephalic vascular systems. Doctoral thesis, Ohio University, Athens.

Porter, W.R. and Witmer, L.M. 2015. Vascular patterns in iguanas and other squamates: blood vessels and sites of thermal exchange. PLoS ONE, 10:e0139215. https://doi.org/10.1371/journal.pone.0139215

Porter, W.R. and Witmer, L.M. 2016. Avian cephalic vascular anatomy, sites of thermal exchange, and the rete ophthalmicum. The Anatomical Record, 299:1461-1486. https://doi.org/10.1002/ar.23375

Porter, W.R. and Witmer, L.M. 2020. Vascular patterns in the heads of dinosaurs: evidence for blood vessels, sites of thermal exchange, and their role in physiological thermoregulatory strategies. The Anatomical Record, 303:1075-1103. https://doi.org/10.1002/ar.24234

Porter, W.R., Sedlmayr, J.C., and Witmer, L.M. 2016. Vascular patterns in the heads of crocodilians: blood vessels and sites of thermal exchange. Journal of Anatomy, 229:800-824. https://doi.org/10.1111/joa.12539

Pusch, L.C., Kammerer, C.F., and Fröbisch, J. 2019. Cranial anatomy of the early cynodont Galesaurus planiceps and the origin of mammalian endocranial characters. Journal of Anatomy, 234:592-621. https://doi.org/10.1111/joa.12958

Pusch, L.C., Ponstein, J., Kammerer, C.F., and Fröbisch, J. 2020. Novel endocranial data on the early therocephalian Lycosuchus vanderrieti underpin high character variability in early theriodont evolution. Frontiers in Ecology and Evolution, 7:464. https://doi.org/10.3389/fevo.2019.00464

Reisz, R.R. and Larson, D. 2016. Dental anatomy and skull length to tooth size ratios support the hypothesis that theropod dinosaurs had lips. Canadian Society of Vertebrate Palaeontology Annual Meeting IV, Mississauga, Canada, p. 49-50.

Rodella, L.F., Buffoli, B., Labanca, M., and Rezzani, R. 2012. A review of the mandibular and maxillary nerve supplies and their clinical relevance. Archives of Oral Biology, 57:323-334. https://doi.org/10.1016/j.archoralbio.2011.09.007

Rothschild, B.M. and Naples, V. 2017. Apparent sixth sense in theropod evolution: the making of a Cretaceous weathervane. PLoS ONE, 12:e0187064. https://doi.org/10.1371/ journal.pone.0187064

Sakagami, R. and Kawabe, S. 2020. Endocranial anatomy of the ceratopsid dinosaur Triceratops and interpretations of sensory and motor function. PeerJ, 8:e9888. https://doi.org/10.7717/ peerj.9888

Saveliev, S.V. and Alifanov, V.R. 2007. A new study of the brain of the predatory dinosaur Tarbosaurus bataar (Theropoda, Tyrannosauridae). Paleontological Journal, 41:281-289. https://doi.org/10.1134/S0031030107030070 
Scanferla A. and Smith, K.T. 2020. Exquisitely preserved fossil snakes of Messel: insight into the evolution, biogeography, habitat preferences and sensory ecology of early boas. Diversity, 12:100. https://doi.org/10.3390/d12030100

Schneider, E.R., Gracheva, E.O., and Bagriantsev, S.N. 2016. Evolutionary specialization of tactile perception in vertebrates. Physiology, 31:193-200. https://doi.org/10.1152/physiol.00036.2015

Schweitzer, M.H., Zheng, W., Organ, C.L., Avci, R., Suo, Z., Freimark, L.M., Lebleu, V.S., Duncan, M.B., Heiden, M.G.V., Neveu, J.M., Lane, W.S., Cottrell, J.S., Horner, J.R., Cantley, L.C., Kalluri, R., and Asara, J. M. 2009. Biomolecular characterization and protein sequences of the Campanian hadrosaur B. canadensis. Science, 324:626-631. https://doi.org/10.1126/science.1165069

Schweitzer, M.H., Zheng, W., Zanno, L., Werning, S., and Sugiyama, T. 2016. Chemistry supports the identification of gender-specific reproductive tissue in Tyrannosaurus rex. Scientific Reports, 6:23099. https://doi.org/10.1038/srep23099

Sedlmayr, J.C. 2002. Anatomy, evolution, and functional significance of cephalic vasculature in Archosauria. Doctoral thesis, Ohio University, Athens.

Sereno, P.C., Wilson, J.A., Witmer, L.M., Whitlock, J.A., Maga, A., Ide, O., and Rowe, T. A. 2007. Structural extremes in a Cretaceous dinosaur. PLoS ONE, 2:e1230. https://doi.org/10.1371/journal.pone.0001230

Serrano-Martínez, A., Knoll, F., Narváez, I., Lautenschlager, S., and Ortega, F. 2020. Neuroanatomical and neurosensorial analysis of the Late Cretaceous basal eusuchian Agaresuchus fontisensis (Cuenca, Spain). Papers in Palaeontology, 7:641-656. https://doi.org/10.1002/spp2.1296

Soares, D. 2002. An ancient sensory organ in crocodilians. Nature, 417:241-242. https://doi.org/10.1038/417241a

Wakimizu, N. and Tsuihiji, T. 2021. Comparative study on the rostral endoskeletal morphology of the trigeminal nervous system in extant archosaurs. The Society of Vertebrate Paleontology 81st Annual Meeting Abstract Book, online, p. 266.

Wallace, R.V.S., Martínez, R., and Rowe T.A. 2019. First record of a basal mammaliamorph from the early Late Triassic Ischigualasto Formation of Argentina. PLoS ONE, 14:e0218791. https://doi.org/10.1371/journal.pone.0218791

Wang, S., Zhang, Q., and Yang, R. 2018. Reevaluation of the dentary structures of caenagnathid oviraptorosaurs (Dinosauria, Theropoda). Scientific Reports, 8:391. https://doi.org/10.1038/s41598-017-18703-1

Watkinson, G.B. 1906. The cranial nerves of Varanus bivittatus. Gegenbaurs Morphologisches Jahrbuch, 35:450-472.

Webb, M. 1957. The ontogeny of the cranial bones, cranial peripheral and cranial parasympathetic nerves, together with a study of the visceral muscles of Struthio. Acta Zoologica, 38:81-203. https://doi.org/10.1111/j.1463-6395.1957.tb00052.x

Willard, W.A. 1915. The cranial nerves of Anolis carolinensis. Bulletin of the Museum of Comparative Zoology, 59:15-116.

Winokur, R.M. and Legler, J.M. 1974. Rostral pores in turtles. Journal of Morphology, 143:107119.

Witmer, L.M. 1995. Homology of facial structures in extant archosaurs (birds and crocodilians), with special reference to paranasal pneumaticity and nasal conchae. Journal of Morphology, 225:269-327. https://doi.org/10.1002/jmor.1052250304

Witmer, L.M. and Ridgely, R.C. 2009. New insights into the brain, braincase, and ear region of tyrannosaurs (Dinosauria, Theropoda), with implications for sensory organization and behavior. The Anatomical Record: Advances in Integrative Anatomy and Evolutionary Biology, 292:1266-1296. https://doi.org/10.1002/ar.20983

Witmer, L.M., Ridgely, R.C., Dufeau, D.L., and Semones, M.C. 2008. Using CT to peer into the past: $3 \mathrm{D}$ visualization of the brain and ear regions of birds, crocodiles, and nonavian dinosaurs, p. 67-87. In Endo, H. and Frey, R. (eds.), Anatomical Imaging. Springer Japan, Tokyo. https://doi.org/10.1007/978-4-431-76933-0_6

Woodward, H.N., Tremaine, K., Williams, S.A., Zanno, L.E., Horner, J.R., and Myhrvold, N. 2020. Growing up Tyrannosaurus rex: osteohistology refutes the pygmy "Nanotyrannus" and supports ontogenetic niche partitioning in juvenile Tyrannosaurus. Science Advances, 6:eaax6250. https://doi.org/10.1126/sciadv.aax6250 
BOUABDELLAH, LESSNER, \& BENOIT: T. REX TRIGEMINAL CANALS

Wynd, B.M., Martínez, R.N., Colombi, C., and Alcober, O. 2020. A review of vertebrate beak morphologies in the Triassic; a framework to characterize an enigmatic beak from the Ischigualasto Formation, San Juan, Argentina. Ameghiniana, 57:370-387.

https://doi.org/10.5710/AMGH.13.05.2020.3313 


\section{APPENDIX 1.}

Three-dimensional models of the skull and neurovascular canals (available for download at http://palaeo-electronica.org/content/2022/3518-t-rex-trigeminal-canals). 